\title{
Tingkat Kecerdasan, Perilaku Belajar, dan Kompetensi Dosen dalam Peningkatan Pemahaman Akuntansi (Sarana Pendidikan sebagai Pemoderasi)
}

\author{
Siti Nafisah Azis \\ nafisahazis@gmail.com \\ Program Studi Akuntansi, Politeknik Negeri Ujung Pandang, Indonesia
}

\begin{abstract}
This research examines the effect of the level intelligence (intellectual intelligence, emotional intelligence, and spiritual intelligence), learning behavior, and competence of lecturers on the level of accounting understanding with educational facilities as moderating variable. The research population was all students majoring in accounting at Politeknik Negeri Ujung Pandang. The sample selection used purposive sampling method that generates total sample of 73 students. This research used primary and secondary data were analyzed using moderation regression analysis with the difference absolute value test. The result of this research showed that intellectual intelligence had a negative effect on the level of accounting understanding. Emotional intelligence and learning behavior had a positive effect on the level of accounting understanding. Spiritual intelligence, competence of lecturers, and educational facilities had no effect on the level of accounting understanding. Educational facilities cannot moderate the effect of the level of intelligence, learning behavior, and competence of lecturer on the level of accounting understanding. Indicators of social skills, being flexible, and practical intelligence influence the level of accounting understanding. This research provides new evidence that educational facilities have not been able to make a real contribution in improving students' understanding of accounting, both as a main and supporting factor.
\end{abstract}

Keywords: level of intelligence; learning behaviour; competence of lecturer; educational facilities; level of accounting understanding

\begin{abstract}
ABSTRAK
Penelitian ini bertujuan menguji pengaruh tingkat kecerdasan (kecerdasan intelektual, kecerdasan emosional, dan kecerdasan spiritual), perilaku belajar, dan kompetensi dosen terhadap tingkat pemahaman akuntansi mahasiswa dengan sarana pendidikan sebagai pemoderasi. Populasi penelitian adalah seluruh mahasiswa jurusan akuntansi Politeknik Negeri Ujung Pandang. Metode pengumpulan sampel yaitu purposive sampling, sehingga menghasilkan jumlah sampel sebesar 73 mahasiswa. Penelitian ini menggunakan data primer dan data sekunder yang dianalisis menggunakan analisis regresi moderasi dengan metode uji selisih mutlak. Hasil menunjukkan bahwa kecerdasan intelektual berpengaruh negatif terhadap tingkat pemahaman akuntansi. Kecerdasan emosional dan perilaku belajar berpengaruh positif terhadap tingkat pemahaman akuntansi. Kecerdasan spiritual, kompetensi dosen, dan sarana pendidikan tidak berpengaruh terhadap tingkat pemahaman akuntansi. Sarana pendidikan juga tidak dapat memoderasi pengaruh tingkat kecerdasan, perilaku belajar, dan kompetensi dosen terhadap tingkat pemahaman akuntansi. Indikator keterampilan sosial, bersikap fleksibel, dan intelegensi praktis memengaruhi tingkat pemahaman akuntansi. Penelitian ini memberikan bukti baru bahwa sarana pendidikan belum dapat memberikan kontribusi nyata dalam peningkatan pemahaman akuntansi mahasiswa, baik sebagai faktor utama maupun faktor penunjang.
\end{abstract}

Kata Kunci: tingkat kecerdasan; perilaku belajar; kompetensi dosen; sarana pendidikan; tingkat pemahaman akuntansi 


\section{PENDAHULUAN}

Tingkat pemahaman akuntansi terlihat dari seberapa banyak teori dan praktik dalam ilmu akuntansi yang dikuasai oleh mahasiswa. Nilai pada mata kuliah akuntansi menjadi indikator pemahaman mahasiswa. Hasil memuaskan yang diperoleh mahasiswa merupakan bukti keberhasilan dosen dalam mendidik mahasiswa. Pemahaman merupakan kemampuan berpikir yang lebih tinggi dari ingatan atau hafalan, sehingga tingkat pemahaman akuntansi mahasiswa menunjukkan kemampuan mahasiswa untuk memahami mata kuliah akuntansi baik secara teori maupun praktik.

Pemahaman pada mata kuliah akuntansi terlihat dari logika berpikir mahasiswa dalam menyelesaikan soal-soal akuntansi yang tercermin pada nilai akhir mahasiswa. Besarnya gap nilai akuntansi di antara mahasiswa menjadi perhatian khusus bagi dosen, karena hal ini menunjukkan ketidakmerataan pemahaman akuntansi mahasiswa. Bagi dosen, hal tersebut bisa menjadi indikator kegagalan dalam mengajar mahasiswa yang berdampak pada menurunnya kualitas pendidikan di universitas tersebut.

Pemahaman bisa diperoleh karena kecerdasan yang dimiliki oleh mahasiswa, perilaku atau gaya belajar mahasiswa, gaya mengajar dosen dan kompetensi dosen, dan didukung oleh lingkungan belajar mahasiswa yaitu sarana pendidikan. Laksmi \& Febrian (2018) menemukan bahwa kecerdasan emosional, kecerdasan sosial, kecerdasan spiritual, perilaku belajar, latar belakang pendidikan menengah, dan asal perguruan tinggi berpengaruh positif terhadap tingkat pemahaman akuntansi mahasiswa.

Kecerdasan merupakan kemampuan berpikir secara rasional, melakukan inovasi, dan memberikan solusi dalam berbagai situasi. Tingkat kecerdasan dapat berupa kecerdasan intelektual, kecerdasan emosional, dan kecerdasan spiritual. Kecerdasan intelektual terdiri atas kemampuan figur, kemampuan verbal, dan kemampuan numerik (Said \& Rahmawati, 2018). Kecerdasan intelektual juga terlihat dari kemampuan berpikir cepat, daya ingat yang kuat, serta kemampuan berpikir secara logis dan sistematis. Kecerdasan intelektual saja tidak cukup untuk mencapai kesuksesan seseorang, melainkan harus didukung dengan kecerdasan emosional dan spiritual. Kecerdasan emosional adalah kemampuan seseorang untuk mengerti, mengenal, mengelola, dan mengendalikan perasaan dan emosi diri sendiri serta orang lain, sehingga terbentuk tingkah laku cerdas yang dipadukan antara pikiran dan tindakan (Said \& Rahmawati, 2018). Sedangkan, kecerdasan spiritual merupakan kecerdasan untuk memecahkan persoalan makna dan nilai. Ciri-ciri orang yang memiliki kecerdasan spiritual yang tinggi, yaitu kemampuan bersikap fleksibel, tingkat kesadaran tinggi, kemampuan mengadaptasi dan memanfaatkan penderitaan, kemampuan menghadapi dan melampaui rasa sakit, kualitas hidup yang diilhami oleh visi dan misi, keengganan untuk menyebabkan kerugian yang tidak perlu, berpandangan holistik, kecenderungan nyata untuk bertanya, dan pemimpin yang penuh pengabdian dan bertanggung jawab (Zohar \& Marshall, 2007).

Satria \& Fatmawati (2017) menemukan bahwa kecerdasan emosional berpengaruh positif terhadap tingkat pemahaman akuntansi mahasiswa di kota Bandung. Laksmi \& Febrian (2018) juga menemukan bahwa kecerdasan emosional, kecerdasan sosial, dan kecerdasan spiritual berpengaruh positif terhadap tingkat pemahaman akuntansi mahasiswa. Hasil ini bertentangan dengan penelitian yang dilakukan oleh Rahayu (2019) yang 
menemukan bahwa kecerdasan intelektual dan kecerdasan emosional tidak berpengaruh terhadap tingkat pemahaman konsep dasar akuntansi, namun stres kuliah memediasi hubungan antara kecerdasan intelektual dan tingkat pemahaman konsep dasar akuntansi.

Mahasiswa yang memiliki tingkat kecerdasan yang tinggi belum tentu dapat memahami suatu konsep dengan baik jika tidak diikuti dengan perilaku belajar yang baik pula. Perilaku belajar mencerminkan kebiasaan belajar mahasiswa yang meliputi kebiasaan mengikuti pelajaran, kebiasaan memantapkan pelajaran, kebiasaan membaca buku, dan kebiasaan menghadapi ujian (Suwardjono, 2005). Perilaku belajar mahasiswa saat ini terlihat menginginkan proses belajar yang instan dan tidak memerlukan usaha yang lebih untuk memeroleh pengetahuan. Mahasiswa lebih memilih mencari materi perkuliahan di internet yang sumbernya tidak valid, dibandingkan dari membaca buku dan artikel-artikel ilmiah. Kebiasaan mengunjungi perpustakaan juga sudah berkurang. Antusias di kelas untuk memahami suatu ilmu juga dirasa menurun. Mahasiswa lebih memilih belajar hanya ketika akan ada ujian, sehingga yang terjadi bukanlah proses memahami melainkan proses menghafal pelajaran.

Mahasiswa yang memiliki perilaku belajar yang baik akan berusaha untuk mempersiapkan bahan yang akan dipelajari sebelum memasuki kelas, selalu mengulang materi yang dipelajari dengan banyak membaca dan mengerjakan latihan soal, berpartisipasi dalam diskusi di kelas, aktif bertanya ketika mengalami kesulitan dalam belajar, dan percaya diri ketika menghadapi ujian dengan tidak melakukan kecurangan dalam ujian. Hasil penelitian-penelitian sebelumnya menunjukkan bahwa perilaku belajar berpengaruh positif terhadap tingkat pemahaman akuntansi (Sari et al., 2017; Laksmi \& Febrian, 2018; Sari \& Sartika, 2018; Listya et al., 2017). Maryati (2017) dan Rahayu (2019) menemukan hal yang sebaliknya yaitu perilaku belajar tidak berpengaruh terhadap tingkat pemahaman akuntansi.

Kemampuan mahasiswa memahami akuntansi bukan hanya dipengaruhi oleh faktor internal dari mahasiswa tersebut, melainkan adanya faktor eksternal yang juga berperan penting dalam meningkatkan pemahaman akuntansi mahasiswa, yaitu kompetensi dosen dan sarana pendidikan. Menurut UU Nomor 14 tahun 2005 Pasal 69 ayat (2), kompetensi dosen meliputi kompetensi pedagogik, kompetensi kepribadian, kompetensi profesional, dan kompetensi sosial. Kompetensi pedagogik adalah kemampuan mengelola pembelajaran peserta didik. Kompetensi kepribadian adalah kemampuan kepribadian yang mantap, berakhlak mulia, arif dan berwibawa serta menjadi teladan peserta didik. Kompetensi profesional adalah kemampuan penguasaan materi pelajaran secara luas dan mendalam. Kompetensi sosial adalah kemampuan untuk berkomunikasi dan berinteraksi secara efektif dan efisien dengan peserta didik. Penelitian yang dilakukan oleh Nugroho et al. (2018) menunjukkan bahwa kompetensi dosen berpengaruh positif terhadap tingkat pemahaman akuntansi. Mulyadi \& Rozak (2019) juga menemukan bahwa kompetensi dan profesionalisme dosen berpengaruh positif terhadap tingkat pemahaman akuntansi. Dosen yang kompeten mampu menghasilkan mahasiswa yang kompeten dalam penguasaan suatu bidang ilmu.

Sarana pendidikan merupakan fasilitas yang diperlukan dalam proses belajar mengajar baik yang bergerak maupun tidak bergerak untuk mencapai tujuan pembelajaran dengan lancar, teratur, efektif, dan efisien (Pitoyo \& Sitawati, 2017). Tersedianya fasilitas belajar 
yang memadai akan mengurangi keluhan mahasiswa terkait ketidaknyamanan saat belajar di kampus yang dianggap sebagai faktor yang menyebabkan mahasiswa sulit untuk berkonsentrasi saat belajar. Pitoyo \& Sitawati (2017) menemukan bahwa sarana pendidikan berpengaruh positif terhadap tingkat pemahaman akuntansi mahasiswa melalui minat belajar, namun sarana pendidikan tidak berpengaruh secara langsung terhadap tingkat pemahaman akuntansi mahasiswa. Nugroho et al. (2018) juga menemukan sarana pendidikan tidak berpengaruh terhadap peningkatan pemahaman akuntansi mahasiswa. Hal ini membuktikan bahwa sarana pendidikan bukan menjadi faktor utama yang berperan dalam peningkatan pemahaman akuntansi, melainkan faktor pendukung yang memperkuat maupun memperlemah faktor-faktor utama dalam meningkatkan pemahaman akuntansi mahasiswa.

Penelitian ini bertujuan untuk menguji pengaruh tingkat kecerdasan yang terdiri atas kecerdasan intelektual, kecerdasan emosional, dan kecerdasan spiritual, perilaku belajar, dan kompetensi dosen terhadap tingkat pemahaman akuntansi mahasiswa. Selain itu, penelitian ini juga menguji peran sarana pendidikan dalam memoderasi pengaruh tingkat kecerdasan, perilaku belajar, dan kompetensi dosen terhadap tingkat pemahaman akuntansi. Penelitian ini berbeda dari penelitian-penelitian sebelumnya, karena pengujian dilakukan secara komprehensif terhadap banyak faktor yang berdasarkan teori dan tinjauan empiris diketahui berkontribusi dalam peningkatan pemahaman akuntansi. Penelitian ini juga memberikan temuan baru yang tidak terdapat pada penelitian-penelitian sebelumnya mengenai peran sarana pendidikan dalam peningkatan pemahaman akuntansi, bukan hanya sebagai faktor utama tetapi juga sebagai faktor penunjang (moderasi) yang berdasarkan teori dianggap mampu memperkuat maupun memperlemah pemahaman akuntansi mahasiswa dengan tercapainya tujuan pembelajaran (Pitoyo \& Sitawati, 2017). Penelitian ini juga diperluas dengan menguji pengaruh dari indikator masing-masing variabel independen terhadap tingkat pemahaman akuntansi.

Kecerdasan manusia adalah kecakapan intelektual yang ditandai oleh prestasi kognitif yang kompleks dan tingkat motivasi dan kesadaran diri yang tinggi. Menurut Firdaus et al. (2019), kecerdasan intelektual adalah kemampuan berpikir secara terarah, berpikir secara rasional, dan menghadapi lingkungannya secara efektif, sehingga dapat membedakan kualitas orang yang satu dengan yang lainnya. Penelitian yang dilakukan oleh Nugroho et al. (2018) menunjukkan bahwa kecerdasan intelektual berpengaruh positif terhadap tingkat pemahaman akuntansi. Hasil ini bertentangan dengan penelitian yang dilakukan oleh Rahayu (2019) yang menemukan kecerdasan intelektual tidak berpengaruh terhadap tingkat pemahaman akuntansi. Mahasiswa yang memiliki tingkat kecerdasan intelektual yang tinggi dianggap memiliki tingkat pemahaman yang tinggi pula. Hal ini dikarenakan kemampuan berpikir yang rasional, terarah, dan sistematis yang mampu mendorong mahasiswa untuk cepat memahami akuntansi yang memerlukan logika berpikir dan daya analisis yang tinggi untuk dapat memahaminya.

\section{H1: Kecerdasan intelektual berpengaruh positif terhadap tingkat pemahaman akuntansi.}

Kecerdasan emosional di dalamnya juga termasuk tiga keterampilan yaitu kesadaran emosional atau kemampuan untuk mengidentifikasi emosi sendiri, kemampuan untuk memanfaatkan emosi tersebut dan menerapkannya ke tugas-tugas seperti berpikir dan 
pemecahan masalah, dan kemampuan untuk mengelola emosi. Suprianto \& Harryoga (2015), Pitoyo \& Sitawati (2017), Sari et al. (2017), Satria \& Fatmawati (2017), Sari \& Sartika (2018), dan Laksmi \& Febrian (2018) menemukan bahwa kecerdasan emosional berpengaruh positif terhadap tingkat pemahaman akuntansi. Hasil penelitian yang dilakukan oleh Laksmi \& Sujana (2017), Nugroho et al. (2018), dan Rahayu (2019) menunjukkan bahawa kecerdasan emosional tidak berpengaruh terhadap tingkat pemahaman akuntansi. Kecerdasan emosional bertentangan dengan kecerdasan intelektual yang merupakan kemampuan kognitif murni yang biasa diukur dengan tes IQ. Mahasiswa yang memiliki tingkat kecerdasan emosional yang tinggi akan mampu mengenali dirinya, mengendalikan diri ketika dihadapkan pada situasi yang sulit, mampu memotivasi diri sendiri dan orang lain, memiliki empati yang tinggi, dan keterampilan sosial yang baik. Melalui kecerdasan emosional tersebut, mahasiswa akan memiliki motivasi yang tinggi dalam memahami ide-ide dan informasi yang baru dan pengendalian diri yang baik untuk mencapai keberhasilan dalam hidupnya. Oleh karena itu, kecerdasan emosional juga berperan penting dalam tingkat pemahaman akuntansi, karena dengan kecerdasan emosional yang tinggi mahasiswa akan memiliki kesabaran, ketekunan, dan bersikap optimis dalam mempelajari akuntansi.

\section{H2: Kecerdasan emosional berpengaruh positif terhadap tingkat pemahaman akuntansi.}

Kecerdasan spiritual terlihat dari kemampuan seseorang untuk menjaga keseimbangan batiniah dan lahiriah. Kecerdasan spritiual melengkapi kecerdasan intelektual dan emosional, sehingga kecerdasan spiritual didefinisikan sebagai kemampuan seseorang untuk mentranspose kecerdasan intelektual dan kecerdasan emosional menuju kebijaksanaan dan pemahaman yang lebih mendalam hingga tercapai kedamaian jiwa. Hasil penelitian yang dilakukan oleh Laksmi \& Sujana (2017), Laksmi \& Febrian (2018) menunjukkan bahwa kecerdasan spiritual berpengaruh positif terhadap tingkat pemahaman akuntansi. Pasek (2016) juga menemukan bahwa kecerdasan spiritual dapat meningkatkan pengaruh kecerdasan intelektual terhadap tingkat pemahaman akuntansi secara positif dan signifikan. Mahasiswa yang memiliki kecerdasan spiritual akan memiliki niat yang tulus dan kesadaran yang tinggi ketika menuntut ilmu, karena menganggap menuntut ilmu adalah bagian dari ibadah. Oleh karena itu, kecerdasan spiritual akan menjadikan mahasiswa bersikap jujur dalam mencapai prestasinya. Berbeda dengan individu yang mengabaikan kecerdasan spiritual akan cenderung menggunakan segala cara untuk mengejar prestasinya termasuk untuk memeroleh nilai yang baik. Kecerdasan spiritual yang tinggi akan menunjang kecerdasan intelektual dan kecerdasan emosional mahasiswa, serta menjadikan mahasiswa mampu berpikir holistik dan berlaku sesuai norma sosial, sehingga memudahkan mahasiswa untuk mempelajari akuntansi yang membutuhkan pandangan secara komprehensif untuk dapat memahaminya.

\section{H3: Kecerdasan spiritual berpengaruh positif terhadap tingkat pemahaman akuntansi.}

Perilaku belajar yang baik akan menjadikan mahasiswa berpartisipasi aktif di kelas, rajin mengerjakan latihan soal tanpa diperintah oleh dosen, terus berupaya belajar hingga dapat memahami suatu ilmu, rajin membaca, membuat catatan dan memahaminya, mengulangi kembali apa yang sudah dipelajari, selalu berkunjung ke perpustakaan, dan selalu berusaha 
agar memiliki buku sendiri untuk dipelajari. Penelitian yang dilakukan oleh Suprianto \& Harryoga (2015), Agustina \& Yanti (2015), Listya et al. (2017), Sari et al. (2017), Laksmi \& Febrian (2018), Nugroho et al. (2018), Sari \& Sartika (2018) menunjukkan bahwa perilaku belajar berpengaruh positif terhadap tingkat pemahaman akuntansi. Maryati (2017) dan Rahayu (2019) menemukan hasil yang berbeda yaitu perilaku belajar tidak berpengaruh terhadap tingkat pemahaman akuntansi. Mahasiswa yang tidak teratur dalam belajar akan memiliki daya tahan belajar yang rendah, dan belajar hanya saat menjelang ujian dapat memengaruhi pemahaman mahasiswa terhadap mata kuliah, sehingga terjadinya penurunan prestasi belajar (Agustina \& Yanti, 2015).

\section{H4: Perilaku belajar berpengaruh positif terhadap tingkat pemahaman akuntansi.}

Kompetensi dosen wajib dikembangkan secara berkelanjutan sejalan dengan perkembangan ilmu pengetahuan, teknologi, dan seni agar dapat menyesuaikan dengan tuntutan zaman yang diperlukan untuk membantu peningkatan pemahaman mahasiswa terhadap suatu bidang ilmu. Nugroho et al. (2018) dan Mulyadi \& Rozak (2019) menemukan bahwa kompetensi dosen berpengaruh positif terhadap tingkat pemahaman akuntansi. Dosen yang kompeten akan menata materi perkuliahan sesuai dengan karakteristik mahasiswa, memahami materi struktur, konsep, dan pola pikir keilmuan yang dapat mendukung perkuliahan, dan memanfaatkan teknologi informasi dan komunikasi dalam proses belajar mengajar yang akan memfasilitasi mahasiswa dalam pencapaian prestasi belajar. Dosen yang memiliki kompetensi profesional akan kreatif dalam mengolah materi pembelajaran. Penyampaian materi akuntansi dilakukan dengan cara yang mudah dipahami oleh mahasiswa, sehingga semakin kompeten seorang dosen di bidangnya, maka semakin besar kemampuannya untuk meningkatkan pemahaman akuntansi mahasiswa.

\section{Hs: Kompetensi dosen berpengaruh positif terhadap tingkat pemahaman akuntansi.}

Sarana pendidikan yang memadai akan menunjang proses pembelajaran mahasiswa. Kelengkapan gedung/ruang kelas akan meningkatkan mutu pendidikan dan kenyamanan mahasiswa dalam menuntut ilmu, sehingga dapat meningkatkan pemahaman mahasiswa terhadap suatu ilmu. Hasil penelitian yang dilakukan oleh Pitoyo \& Sitawati (2017) menunjukkan bahwa sarana pendidikan berpengaruh positif terhadap tingkat pemahaman akuntansi melalui minat belajar, namun secara langsung sarana pendidikan tidak berpengaruh terhadap tingkat pemahaman akuntansi. Nugroho et al. (2018) juga menemukan hasil yang sama yaitu sarana pendidikan dalam hal ini fasilitas belajar tidak berpengaruh terhadap tingkat pemahaman akuntansi. Sarana pendidikan tidak terbukti memberikan pengaruh langsung terhadap tingkat pemahaman akuntansi. Hal ini menunjukkan bahwa sarana pendidikan bukanlah faktor utama yang memengaruhi tingkat pemahaman akuntansi mahasiswa, melainkan dapat dianggap sebagai faktor pendukung dalam pencapaian tujuan pembelajaran. Oleh karena itu, penyelenggara pendidikan masih dianggap perlu untuk menyediakan sarana pendidikan yang lengkap untuk mendukung proses belajar mengajar terjadi secara optimal, sehingga mahasiswa dengan mudah memahami materi pembelajaran akuntansi baik teori maupun praktikum.

\section{H6: Sarana pendidikan memoderasi pengaruh kecerdasan intelektual terhadap tingkat pemahaman akuntansi.}




\section{H7: Sarana pendidikan memoderasi pengaruh kecerdasan emosional terhadap tingkat} pemahaman akuntansi.

Hs: Sarana pendidikan memoderasi pengaruh kecerdasan spiritual terhadap tingkat pemahaman akuntansi.

H9: Sarana pendidikan memoderasi pengaruh perilaku belajar terhadap tingkat pemahaman akuntansi.

H10: Sarana pendidikan memoderasi pengaruh kompetensi dosen terhadap tingkat pemahaman akuntansi.

\section{METODE PENELITIAN}

Penelitian ini adalah penelitian kuantitatif. Jenis data yang digunakan yaitu data primer yang diperoleh dari kuesioner online dengan skala likert empat poin dan data sekunder yang berupa nilai akuntansi mahasiswa yang diperoleh dari sistem informasi akademik (simak). Populasi penelitian ini adalah seluruh mahasiswa jurusan akuntansi Politeknik Negeri Ujung Pandang. Metode pengumpulan sampel yaitu purposive sampling, sehingga menghasilkan sampel sebanyak 73 mahasiswa. Tabel 1 menunjukkan ringkasan pengumpulan sampel berdasarkan kriteria pada penelitian ini.

Tabel 1. Ringkasan Pengumpulan Sampel

\begin{tabular}{|c|c|}
\hline Proses Pengumpulan Sampel & Jumlah \\
\hline $\begin{array}{l}\text { Jumlah mahasiswa semester akhir angkatan } 2016 \text { (D4 Akuntansi Manajerial) dan } \\
\text { angkatan } 2017 \text { (D3 Akuntansi) yang telah mengambil seluruh mata kuliah } \\
\text { akuntansi (teori dan praktik) }\end{array}$ & 187 \\
\hline Jumlah mahasiswa yang tidak mengisi kuesioner & $(15)$ \\
\hline Jumlah mahasiswa yang mengisi kuesioner & 172 \\
\hline $\begin{array}{l}\text { Mahasiswa yang lebih dari satu kali mengisi kuesioner (terdapat } 2 \text { atau lebih } \\
\text { kuesioner dengan nama yang sama) }\end{array}$ & $(5)$ \\
\hline $\begin{array}{l}\text { Jumlah mahasiswa yang tidak menulis nama pada kuesioner dan/atau memakai } \\
\text { inisial }\end{array}$ & (94) \\
\hline Jumlah kuesioner yang dapat diolah & 73 \\
\hline
\end{tabular}

Variabel dependen pada penelitian ini yaitu tingkat pemahaman akuntansi yang diproksikan dengan nilai akuntansi mahasiswa, sedangkan kecerdasan intelektual, kecerdasan emosional, kecerdasan spiritual, perilaku belajar, dan kompetensi dosen adalah variabel independen. Variabel moderasi yang digunakan adalah sarana pendidikan. Definisi operasional dari setiap variabel ditunjukkan pada tabel 2.

Tabel 2. Definisi Operasional Variabel

\begin{tabular}{|c|c|c|c|}
\hline Variabel & Operasional Variabel & Indikator/Pengukuran & Skala \\
\hline $\begin{array}{l}\text { Tingkat } \\
\text { Pemahaman } \\
\text { Akuntansi }\end{array}$ & $\begin{array}{l}\text { Kemampuan untuk } \\
\text { memahami akuntansi, } \\
\text { baik sebagai seperangkat } \\
\text { pengetahuan, maupun } \\
\text { sebagai proses atau } \\
\text { praktik (Satria dan } \\
\text { Fatmawati, 2017). }\end{array}$ & $\begin{array}{l}\text { Total nilai akhir mata kuliah akuntansi } \\
\text { mahasiswa yang diproksikan dengan } \\
\text { angka mutu }(\mathrm{AM}) \text {, yaitu } \mathrm{A}=4,0, \mathrm{~B}+= \\
3,5, \mathrm{~B}=3,0, \mathrm{C}+=2,5, \mathrm{C}=2,0, \mathrm{D}=1,0 \text {, dan } \\
\mathrm{E}=0 \text {. } \\
\text { Mata kuliah akuntansi yang diukur terdiri } \\
\text { atas; (a) Pengantar Akuntansi } 1 \text { dan } 2 \text {, } \\
\text { Akuntansi Dasar, (b) Akuntansi }\end{array}$ & Rasio \\
\hline
\end{tabular}




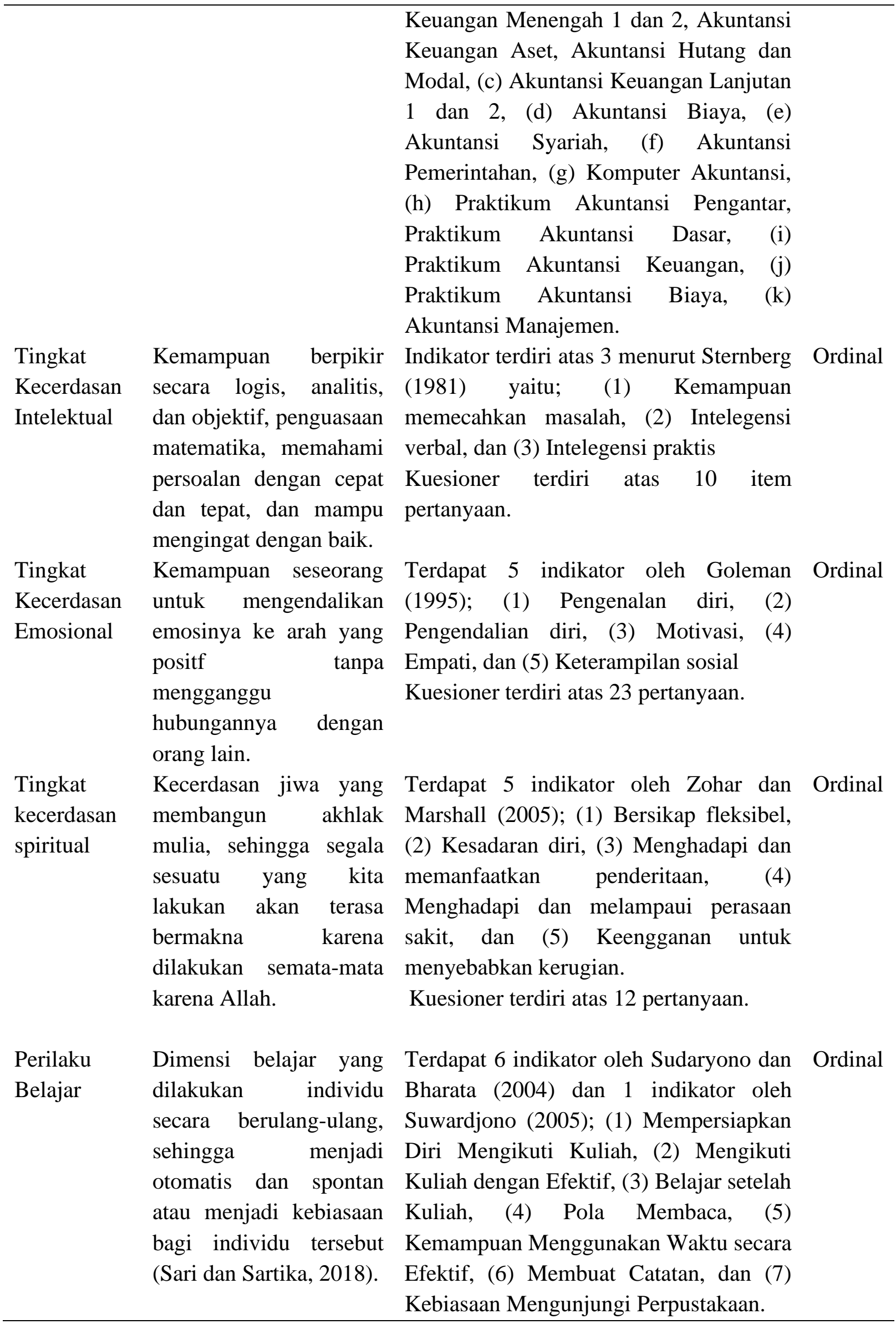




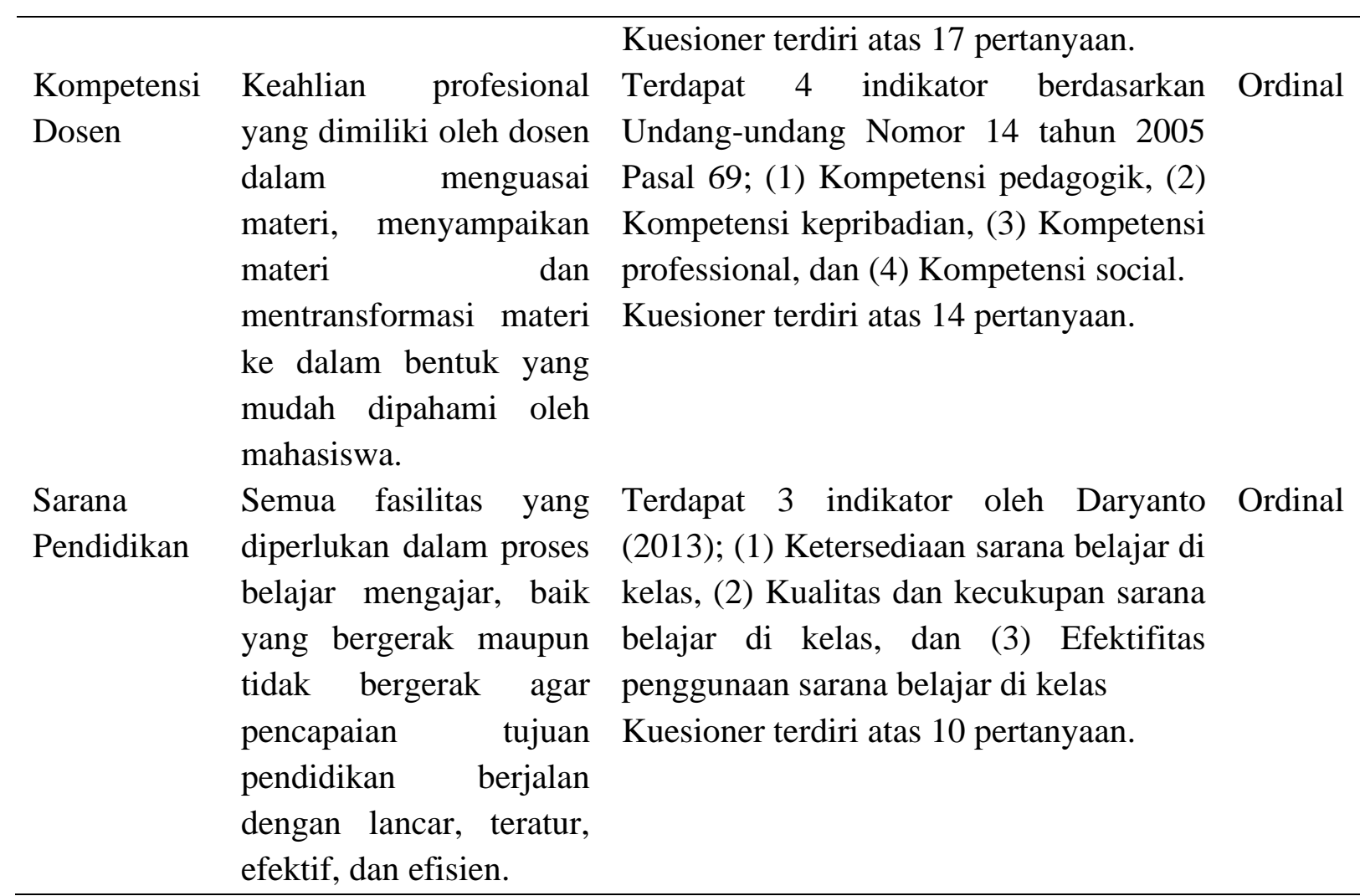

Teknik analisis data menggunakan analisis regresi berganda untuk menguji pengaruh langsung dan analisis regresi moderasi dengan metode uji selisih mutlak untuk menguji pengaruh variabel moderasi. Kualitas data juga diuji menggunakan uji validitas dan reliabilitas. Penelitian ini juga menggunakan uji asumsi klasik yang terdiri atas uji normalitas, multikolinearitas, heteroskedastisitas (uji glejser), dan autokorelasi. Model regresi yang digunakan dalam penelitian ini adalah sebagai berikut.

$$
\begin{aligned}
\text { TPA } & =\beta 0+\beta 1 \mathrm{KI}+\beta 2 \mathrm{KE}+\beta 3 \mathrm{KS}+\beta 4 \mathrm{~PB}+\beta 5 \mathrm{KD}+\beta 6 \mathrm{SP}+\mathrm{e}(\operatorname{model} 1) \\
\mathrm{TPA} & =\beta 0+\beta 1 \mathrm{KI}+\beta 2 \mathrm{KE}+\beta 3 \mathrm{KS}+\beta 4 \mathrm{~PB}+\beta 5 \mathrm{KD}+\beta 6 \mathrm{SP}+\beta 7|\mathrm{KI}-\mathrm{SP}|+\beta 8|\mathrm{KE}-\mathrm{SP}| \\
& +\beta 9|\mathrm{KS}-\mathrm{SP}|+\beta 10|\mathrm{~PB}-\mathrm{SP}|+\beta 11|\mathrm{KD}-\mathrm{SP}|+\mathrm{e}(\operatorname{model} 2)
\end{aligned}
$$

Keterangan: TPA $=$ Tingkat Pemahaman Akuntansi, KI= Kecerdasan Intelektual, $\mathrm{KE}=$ Kecerdasan Emosional, $\mathrm{KS}=$ Kecerdasan Spiritual, $\mathrm{PB}=$ Perilaku Belajar, $\mathrm{KD}=$ Kompetensi Dosen, $\mathrm{SP}=$ Sarana Pendidikan

\section{HASIL DAN PEMBAHASAN}

Tabel 3 menunjukkan distribusi responden, dimana proporsi responden perempuan jauh lebih besar dibandingkan responden laki-laki yaitu sebesar 78,08\%. Responden laki-laki hanya sebesar 21,92\%. Dari 73 mahasiswa, sebanyak 58,90\% berasal dari program studi D3 akuntansi (angkatan 2017), sedangkan $41,10 \%$ berasal dari prodi D4 akuntansi manajerial (angkatan 2016). Responden mayoritas memiliki IPK di atas 3,00, yaitu sebesar 87,67\%. Tabel 4 adalah hasil uji validitas dari seluruh indikator variabel yang digunakan dalam penelitian ini yang menunjukkan bahwa seluruh indikator variabel yang digunakan adalah valid, karena nilai Pearson Correlation bernilai positif dan nilai sig. (2-tailed) di bawah 0,05. Hasil uji reliabilitas pada tabel 5 juga menunjukkan bahwa semua variabel dinyatakan reliabel, karena nilai Cronbach's Alpha di atas 0,6.

Tabel 3. Distribusi Responden 


\begin{tabular}{lccccc}
\hline \multicolumn{1}{c}{ Jenis Kelamin } & Jumlah & Persentase & IPK & Jumlah & Persentase \\
\hline Laki-laki & 16 & $21,92 \%$ & $<3,00$ & 7 & $9,59 \%$ \\
Perempuan & 57 & $78,08 \%$ & $=3,00$ & 2 & $2,74 \%$ \\
Total & 73 & $100 \%$ & $>3,00$ & 64 & $87,67 \%$ \\
& & & & 73 & $100 \%$ \\
\hline Program Studi/Angkatan & Jumlah & Persentase & & \\
\hline D3/2017 & 43 & $58,90 \%$ & & \\
D4/2016 & 30 & $41,10 \%$ & & & \\
Total & 73 & $100 \%$ & & & \\
\hline
\end{tabular}

Sumber: Data primer diolah (2020)

Tabel 4. Uji Validitas

\begin{tabular}{|c|c|c|c|c|c|c|c|c|}
\hline Indikator & Korelasi & Sig. & Indikator & Korelasi & Sig. & Indikator & Korelasi & Sig. \\
\hline $\mathrm{X} 1.1$ & 0,716 & 0,000 & $\mathrm{X} 2.1$ & 0,417 & 0,000 & $\mathrm{X} 2.14$ & 0,545 & 0,000 \\
\hline $\mathrm{X} 1.2$ & 0,663 & 0,000 & $\mathrm{X} 2.2$ & 0,458 & 0,000 & $\mathrm{X} 2.15$ & 0,496 & 0,000 \\
\hline $\mathrm{X} 1.3$ & 0,659 & 0,000 & $\mathrm{X} 2.3$ & 0,514 & 0,000 & $\mathrm{X} 2.16$ & 0,544 & 0,000 \\
\hline $\mathrm{X} 1.4$ & 0,703 & 0,000 & $\mathrm{X} 2.4$ & 0,544 & 0,000 & X2.17 & 0,577 & 0,000 \\
\hline $\mathrm{X} 1.5$ & 0,632 & 0,000 & $\mathrm{X} 2.5$ & 0,593 & 0,000 & X2.18 & 0,589 & 0,000 \\
\hline X1.6 & 0,597 & 0,000 & $\mathrm{X} 2.6$ & 0,417 & 0,000 & $X 2.19$ & 0,674 & 0,000 \\
\hline $\mathrm{X} 1.7$ & 0,675 & 0,000 & $\mathrm{X} 2.7$ & 0,410 & 0,000 & $\mathrm{X} 2.20$ & 0,718 & 0,000 \\
\hline $\mathrm{X} 1.8$ & 0,637 & 0,000 & $\mathrm{X} 2.8$ & 0,580 & 0,000 & $X 2.21$ & 0,676 & 0,000 \\
\hline X1.9 & 0,469 & 0,000 & X2.9 & 0,711 & 0,000 & $\mathrm{X} 2.22$ & 0,618 & 0,000 \\
\hline \multirow[t]{4}{*}{$\mathrm{X} 1.10$} & 0,478 & 0,000 & $\mathrm{X} 2.10$ & 0,570 & 0,000 & $X 2.23$ & 0,515 & 0,000 \\
\hline & & & $\mathrm{X} 2.11$ & 0,505 & 0,000 & & & \\
\hline & & & $\mathrm{X} 2.12$ & 0,680 & 0,000 & & & \\
\hline & & & $\mathrm{X} 2.13$ & 0,640 & 0,000 & & & \\
\hline $\mathrm{X} 2.1$ & 0,435 & 0,000 & $\mathrm{X} 4.1$ & 0,549 & 0,000 & $\mathrm{X} 4.13$ & 0,790 & 0,000 \\
\hline $\mathrm{X} 2.2$ & 0,522 & 0,000 & $\mathrm{X} 4.2$ & 0,419 & 0,000 & $\mathrm{X} 4.14$ & 0,702 & 0,000 \\
\hline $\mathrm{X} 2.3$ & 0,493 & 0,000 & $\mathrm{X} 4.3$ & 0,499 & 0,000 & $\mathrm{X} 4.15$ & 0,628 & 0,000 \\
\hline $\mathrm{X} 2.4$ & 0,617 & 0,000 & $\mathrm{X} 4.4$ & 0,562 & 0,000 & $\mathrm{X} 4.16$ & 0,585 & 0,000 \\
\hline $\mathrm{X} 2.5$ & 0,526 & 0,000 & $\mathrm{X} 4.5$ & 0,585 & 0,000 & X4.17 & 0,748 & 0,000 \\
\hline $\mathrm{X} 2.6$ & 0,575 & 0,000 & $\mathrm{X} 4.6$ & 0,674 & 0,000 & $\mathrm{X} 4.18$ & 0,630 & 0,000 \\
\hline $\mathrm{X} 2.7$ & 0,629 & 0,000 & $\mathrm{X} 4.7$ & 0,716 & 0,000 & & & \\
\hline $\mathrm{X} 2.8$ & 0,571 & 0,000 & $\mathrm{X} 4.8$ & 0,698 & 0,000 & & & \\
\hline X2.9 & 0,565 & 0,000 & X4.9 & 0,664 & 0,000 & & & \\
\hline $\mathrm{X} 2.10$ & 0,615 & 0,000 & $\mathrm{X} 4.10$ & 0,718 & 0,000 & & & \\
\hline $\mathrm{X} 2.11$ & 0,488 & 0,000 & X4.11 & 0,535 & 0,000 & & & \\
\hline $\mathrm{X} 2.12$ & 0,617 & 0,000 & $\mathrm{X} 4.12$ & 0,756 & 0,000 & & & \\
\hline X5.1 & 0,654 & 0,000 & X6.1 & 0,734 & 0,000 & & & \\
\hline X5.2 & 0,672 & 0,000 & X6.2 & 0,474 & 0,000 & & & \\
\hline X5.3 & 0,731 & 0,000 & X6.3 & 0,709 & 0,000 & & & \\
\hline X5.4 & 0,750 & 0,000 & X6.4 & 0,749 & 0,000 & & & \\
\hline X5.5 & 0,754 & 0,000 & X6.5 & 0,669 & 0,000 & & & \\
\hline X5.6 & 0,750 & 0,000 & X6.6 & 0,674 & 0,000 & & & \\
\hline
\end{tabular}




\begin{tabular}{cccccc} 
X5.7 & 0,743 & 0,000 & X6.7 & 0,761 & 0,000 \\
X5.8 & 0,713 & 0,000 & X6.8 & 0,592 & 0,000 \\
X5.9 & 0,634 & 0,000 & X6.9 & 0,607 & 0,000 \\
X5.10 & 0,711 & 0,000 & X6.10 & 0,471 & 0,000 \\
X5.11 & 0,685 & 0,000 & & & \\
X5.12 & 0,706 & 0,000 & & & \\
X5.13 & 0,752 & 0,000 & & & \\
X5.14 & 0,738 & 0,000 & & & \\
\hline
\end{tabular}

Notasi: $\mathrm{X} 1=$ indikator dari $\mathrm{KI}, \mathrm{X} 2=$ indikator dari $\mathrm{KE}, \mathrm{X} 3=$ indikator dari $\mathrm{KS}, \mathrm{X} 4=$ indikator dari $\mathrm{PB}, \mathrm{X} 5=$ indikator dari $\mathrm{KD}, \mathrm{X} 6=$ indikator dari $\mathrm{SP}$

Sumber: Data primer diolah (2020)

Tabel 5. Uji Reliabilitas

\begin{tabular}{lcc}
\hline Variabel & Cronbach's Alpha & Hasil \\
\hline Kecerdasan Intelektual & 0,825 & Reliabel \\
Kecerdasan Emosional & 0,898 & Reliabel \\
Kecerdasan Spiritual & 0,787 & Reliabel \\
Perilaku Belajar & 0,912 & Reliabel \\
Kompetensi Dosen & 0,921 & Reliabel \\
Sarana Pendidikan & 0,839 & Reliabel
\end{tabular}

Sumber: Data primer diolah (2020)

Hasil uji normalitas untuk model 1 dan 2 menunjukkan nilai signifikansi KolmogorovSmirnov sebesar 0,200 dan 0,211, sehingga tidak terjadi masalah normalitas karena nilai signifikansi di atas 0,05 . Hasil uji multikolinearitas pada model 1 dan 2 menunjukkan nilai VIF tidak lebih dari 10 dan nilai tolerance tidak kurang dari 0,1 . Hasil uji glejser juga menunjukkan angka signifikansi di atas 0,05 untuk semua variabel, sehingga tidak terjadi heteroskedastisitas. Nilai Durbin-Watson untuk model 1 yaitu 1,962 dan model 2 yaitu 1,913, sehingga tidak terjadi auttokorelasi karena nilai $\mathrm{DW}>\mathrm{dL}(1,4480)$ dan $\mathrm{DW}>\mathrm{dU}(1,8016)$. Tabel 6 menunjukkan hasil uji asumsi klasik penelitian ini.

Tabel 6. Uji Asumsi Klasik

\begin{tabular}{lcccccc}
\hline & \multicolumn{2}{c}{ Normalitas } & \multicolumn{2}{c}{ Multikoliniaritas } & Heteroskedastisitas & Autokorelasi \\
\cline { 2 - 7 } & $\begin{array}{c}\text { Kolmogorov- } \\
\text { Smirnov }\end{array}$ & Sig. & VIF & Tolerance & Sig. & DW \\
\hline Model & 0,089 & 0,200 & & & & 1,962 \\
1: & & & 0,512 & 1,953 & 0,107 & \\
KI & & & 0,606 & 1,651 & 0,411 & \\
KE & & & 0,450 & 2.224 & 0,337 & \\
KS & & & 0,625 & 1,600 & 0,901 & \\
PB & & & 0,543 & 1,842 & 0,574 & \\
KD & & & 0,781 & 1,280 & 0,335 & \\
SP & & & & & & 1,913 \\
Model & 0,093 & 0,211 & & & & \\
2: & & & 0,485 & 2,061 & 0,166 & \\
KI & & & & & &
\end{tabular}




\begin{tabular}{llll} 
KE & 0,541 & 1,847 & 0,947 \\
KS & 0,434 & 2,303 & 0,563 \\
PB & 0,608 & 1,643 & 0,993 \\
KD & 0,514 & 1,947 & 0,338 \\
SP & 0,758 & 1,320 & 0,269 \\
$\mid$ KI-SP| & 0,508 & 1,968 & 0,226 \\
$\mid$ KE-SP| & 0,418 & 2,390 & 0,622 \\
$\mid$ KS-SP| & 0,577 & 1,734 & 0,502 \\
$\mid$ PB-SP| & 0,622 & 1,608 & 0,288 \\
$\mid$ KD-SP| & 0,626 & 1,597 & 0,294 \\
\hline
\end{tabular}

Sumber: Data primer diolah (2020)

Hasil uji regresi pada model pertama menunjukkan nilai adjusted R square sebesar 0,059 artinya luasnya pengaruh langsung variabel independen (KI, KE, KS, PB, KD, dan SP) terhadap variabel dependen TPA hanya sebesar 5,9\%, sisanya sebesar 94,1\% dijelaskan oleh variabel lain yang tidak diteliti dalam penelitian ini. Pada model 2, nilai adjusted $\mathrm{R}$ square sebesar 0,050 yang berarti luasnya pengaruh variabel independen dan variabel moderasi terhadap variabel dependen pada penelitian hanya dapat dijelaskan sebesar 5\%. Tabel 7 menunjukkan hasil uji hipotesis penelitian ini.

Tabel 7. Uji Hipotesis

\begin{tabular}{llccc}
\hline \multicolumn{1}{c}{ Hipotesis } & B & Sig. & Keputusan \\
\hline $\mathrm{H}_{1}$ & $\begin{array}{l}\text { Kecerdasan intelektual berpengaruh positif terhadap } \\
\text { tingkat pemahaman akuntansi }\end{array}$ & $-0,354$ & 0,041 & Ditolak \\
$\mathrm{H}_{2}$ & $\begin{array}{l}\text { Kecerdasan emosional berpengaruh positif terhadap } \\
\text { tingkat pemahaman akuntansi }\end{array}$ & 0,177 & 0,036 & Diterima \\
$\mathrm{H}_{3}$ & $\begin{array}{l}\text { Kecerdasan spiritual berpengaruh positif terhadap } \\
\text { tingkat pemahaman akuntansi }\end{array}$ & $-0,006$ & 0,973 & Ditolak \\
$\mathrm{H}_{4}$ & $\begin{array}{l}\text { Perilaku belajar berpengaruh positif terhadap tingkat } \\
\text { pemahaman akuntansi }\end{array}$ & 0,168 & 0,034 & Diterima \\
$\mathrm{H}_{5} \quad \begin{array}{l}\text { Kompetensi dosen berpengaruh positif terhadap } \\
\text { tingkat pemahaman akuntansi }\end{array}$ & $-0,081$ & 0,495 & Ditolak \\
$\mathrm{H}_{6} \quad \begin{array}{l}\text { Sarana pendidikan memoderasi pengaruh kecerdasan } \\
\text { intelektual terhadap tingkat pemahaman akuntansi }\end{array}$ & 1,217 & 0,177 & Ditolak \\
$\mathrm{H}_{7} \quad \begin{array}{l}\text { Sarana pendidikan memoderasi pengaruh kecerdasan } \\
\text { emosional terhadap tingkat pemahaman akuntansi }\end{array}$ & $-1,008$ & 0,286 & Ditolak \\
$\mathrm{H}_{8}$ & $\begin{array}{l}\text { Sarana pendidikan memoderasi pengaruh kecerdasan } \\
\text { spiritual terhadap tingkat pemahaman akuntansi }\end{array}$ & 1,217 & 0,572 & Ditolak \\
$\mathrm{H}_{9}$ & $\begin{array}{l}\text { Sarana pendidikan memoderasi pengaruh perilaku } \\
\text { belajar terhadap tingkat pemahaman akuntansi }\end{array}$ & $-0,620$ & 0,507 & Ditolak \\
$\mathrm{H}_{10}$ & $\begin{array}{l}\text { Sarana pendidikan memoderasi pengaruh kompetensi } \\
\text { dosen terhadap tingkat pemahaman akuntansi }\end{array}$ & 0,700 & 0,397 & Ditolak \\
\hline $\mathrm{S}^{2}$ & & & \\
\hline
\end{tabular}

Sumber: Data primer diolah (2020)

Hasil uji hipotesis menunjukkan nilai signifikansi untuk variabel kecerdasan intelektual sebesar 0,041 dan koefisien regresi sebesar -0,354. Hal ini berarti kecerdasan intelektual 
berpengaruh negatif terhadap tingkat pemahaman akuntansi, sehingga $\mathrm{H}_{1}$ ditolak. Hasil uji per indikator dari variabel kecerdasan intelektual menunjukkan bahwa indikator intelegensi praktis yang memiliki pengaruh negatif terhadap tingkat pemahaman akuntansi dengan nilai signifikansi sebesar 0,005 dan koefisien regresi sebesar -1,568. Intelegensi praktis merupakan kemampuan untuk dapat mengatasi sesuatu yang sulit dalam pekerjaan yang berlangsung secara cepat dan tepat. Selain intelegensi praktis terdapat juga intelegensi teoritis, yaitu kemampuan untuk mendapatkan suatu pikiran penyelesaian soal atau masalah dengan cepat dan tepat. Hasil penelitian ini tidak sejalan dengan penelitian sebelumnya yang dilakukan oleh Nugroho et al. (2018) yang menemukan kecerdasan intelektual berpengaruh positif terhadap tingkat pemahaman akuntansi dan Rahayu (2019) yang menemukan kecerdasan intelektual tidak berpengaruh terhadap tingkat pemahaman akuntansi.

Bagi mahasiswa, akuntansi dapat dipahami jika mampu menganalisis soal atau teori yang dikerjakan dan menemukan logika dari soal tersebut. Hal ini cenderung kepada karakteristik intelegensi teoritis yang merupakan intelegensi dalam memecahkan soal atau masalah yang bersifat teoritis secara cepat dan tepat. Berpengaruh negatifnya hasil penelitian ini dapat disebabkan oleh instrumen yang digunakan tidak memasukkan indikator intelegensi teoritis dan karakteristik responden yang berasal dari politeknik yang memberikan porsi yang lebih besar pada mata kuliah praktik dibandingkan teori, sehingga mahasiswa cenderung memiliki intelegensi praktik yang lebih besar. Hasil ini tidak dapat disimpulkan bahwa mahasiswa yang memiliki intelegensi praktik lebih besar akan memiliki kemampuan teoritis yang lebih kecil, karena penelitian ini belum memasukkan indikator intelegensi teoritis di dalamnya.

Pengaruh kecerdasan emosional terhadap tingkat pemahaman akuntansi memiliki nilai koefisien regresi sebesar 0,177 dan nilai signifikansi sebesar 0,036, yang artinya kecerdasan emosional berpengaruh positif terhadap tingkat pemahaman akuntansi, sehingga $\mathrm{H} 2$ diterima. Hasil penelitian ini konsisten dengan penelitian yang dilakukan oleh Suprianto \& Harryoga (2015), Pitoyo \& Sitawati (2017), Sari et al. (2017), Satria \& Fatmawati (2017), Sari \& Sartika (2018), dan Laksmi \& Febrian (2018), namun tidak sejalan dengan hasil penelitian Laksmi \& Sujana (2017), Nugroho et al. (2018), dan Rahayu (2019) yang menemukan kecerdasan emosional tidak berpengaruh terhadap tingkat pemahaman akuntansi. Indikator keterampilan sosial dari variabel kecerdasan emosional ditemukan berpengaruh positif terhadap tingkat pemahaman akuntansi dengan nilai koefisien regresi sebesar 0,734 dan nilai signifikansi sebesar 0,045. Mahasiswa yang memiliki kecerdasan emosional yang tinggi akan mudah mengendalikan emosi, sehingga akan lebih bersabar ketika dihadapkan pada masalah yang sulit seperti ketika berusaha memahami akuntansi baik teori maupun praktik. Indikator keterampilan sosial yang tinggi mencerminkan mahasiswa memiliki kemampuan memecahkan masalah ketika banyak perbedaan pendapat yang menyebabkan konflik dan keterampilan dalam menghidupkan suasana ketika berdiskusi, dimana diskusi merupakan salah satu cara belajar yang dapat membantu mahasiswa untuk mempelajari akuntansi.

Pada tabel 7, kecerdasan spiritual tidak terbukti memengaruhi tingkat pemahaman akuntansi, karena nilai signifikansi 0,973 dan nilai koefisien regresi $-0,006$ sehingga $\mathrm{H}_{3}$ ditolak. Namun, jika dilihat dari hasil uji per indikator ditemukan bahwa indikator bersikap fleksibel berpengaruh negatif terhadap tingkat pemahaman akuntansi dengan nilai koefisien 
regresi -1,401 dan nilai signifikansi 0,038. Hasil penelitian ini tidak konsisten dengan penelitian yang dilakukan oleh Laksmi \& Sujana (2017) dan Laksmi \& Febrian (2018) yang menemukan bahwa kecerdasan spiritual berpengaruh positif terhadap tingkat pemahaman akuntansi. Kecerdasan spiritual tidak berpengaruh terhadap tingkat pemahaman akuntansi sama halnya dengan kecerdasan intelektual. Hasil ini sejalan dengan teori yang menyatakan bahwa kecerdasan spiritual yang tinggi dapat mendukung kecerdasan intelektual. Pasek (2016) menemukan bahwa kecerdasan spiritual dapat meningkatkan pengaruh kecerdasan intelektual terhadap tingkat pemahaman akuntansi secara positif dan signifikan.

Perilaku belajar menunjukkan nilai koefisien regresi sebesar 0,168 dan nilai signifikansi sebesar 0,034, yang berarti perilaku belajar berpengaruh positif terhadap tingkat pemahaman akuntansi, sehingga H4 diterima. Hasil ini konsisten dengan penelitian yang dilakukan oleh Suprianto \& Harryoga (2015), Agustina \& Yanti (2015), Listya et al. (2017), Sari et al. (2017), Laksmi \& Febrian (2018), Nugroho et al. (2018), Sari \& Sartika (2018), namun tidak sejalan dengan penelitian Maryati (2017) dan Rahayu (2019) yang menemukan perilaku belajar tidak berpengaruh terhadap tingkat pemahaman akuntansi. Perilaku belajar yang baik akan menjadikan belajar sebagai suatu kebutuhan bagi mahasiswa. Perilaku belajar yang baik seperti mempersiapkan diri sebelum mengikuti kuliah, mengikuti kuliah dengan efektif, membuat catatan, belajar setelah kuliah, belajar untuk menghadapi ujian, pola membaca yang baik, dan kemampuan menggunakan waktu secara efektif akan memudahkan mahasiswa dalam memahami suatu ilmu pengetahuan terutama akuntansi yang membutuhkan ketekunan dalam mempelajarinya.

Kompetensi dosen tidak berpengaruh terhadap tingkat pemahaman akuntansi, karena nilai signifikansi sebesar 0,495 dan nilai koefisien regresi -0,081, sehingga H5 ditolak. Hasil ini tidak konsisten dengan penelitian yang dilakukan oleh Nugroho et al. (2018) dan Mulyadi \& Rozak (2019) yang menemukan bahwa kompetensi dosen berpengaruh positif terhadap tingkat pemahaman akuntansi. Namun, hasil penelitian ini sejalan dengan penelitian yang dilakukan oleh Al-Mutairi (2011) di Kuwait dan Murti \& Prasetio (2018) yang menemukan bahwa kompetensi dosen tidak berpengaruh terhadap prestasi akademik mahasiswa. Hasil ini menunjukkan bahwa dosen hanya sebagai fasilitator dan motivator bagi mahasiswa, terutama di era revolusi industri saat ini dimana berbagai ilmu pengetahuan dapat diakses dengan mudah tanpa batas ruang dan waktu, sehingga mahasiswa pun bisa belajar secara mandiri. Dosen dan mahasiswa dianggap memiliki tingkat pengetahuan yang sama, karena tidak ada lagi informasi yang tidak bisa diketahui di era teknologi informasi ini. Dosen hanya memberikan fasilitas kepada mahasiswa, dan selebihnya mahasiswa yang berkreasi sendiri dan berinisiatif dalam aktivitas belajarnya.

Hasil penelitian ini juga menunjukkan bahwa sarana pendidikan tidak berhasil memengaruhi tingkat pemahaman akuntansi baik secara langsung $($ sig.=0,929) maupun sebagai pemoderasi. Sarana pendidikan tidak memoderasi pengaruh kecerdasan intelektual, kecerdasan emosional, kecerdasan spiritual, perilaku belajar, dan kompetensi dosen terhadap tingkat pemahaman akuntansi, karena memiliki tingkat signifikansi secara berturut-turut sebesar 0,177, 0,286, 0,572, 0,507, dan 0,397, sehingga H6, H7, H8, H9, dan H10 ditolak. Hasil penelitian ini konsisten dengan penelitian yang dilakukan oleh oleh Pitoyo \& Sitawati (2017) dan Nugroho et al. (2018) yang menemukan sarana pendidikan tidak berpengaruh 
secara langsung terhadap tingkat pemahaman akuntansi, sedangkan untuk pengujian sebagai moderasi, penelitian ini memberikan temuan baru yang yang menunjukkan bahwa sarana pendidikan tidak dapat memoderasi pengaruh dari variabel KI, KE, KS, PB dan KD terhadap tingkat pemahaman akuntansi. Hal ini tidak sejalan dengan teori yang menyatakan bahwa sarana pendidikan dapat menjadi faktor pendukung yang menunjang proses belajar mengajar sehingga memperbaiki kualitas pendidikan (Peraturan Pemerintah No. 19 Tahun 2005 Bab VII Pasal 42 tentang Standar Nasional Pendidikan). Namun, hasil penelitian ini masih membutuhkan penelitian-penelitian selanjutnya yang lebih komprehensif agar hasilnya dapat diperbandingkan, karena kemungkinan adanya faktor lain yang menyebabkan tidak berpengaruhnya sarana pendidikan terhadap tingkat pemahaman akuntansi baik sebagai faktor utama (pengaruh langsung) maupun sebagai penunjang (pemoderasi).

\section{KESIMPULAN}

Penelitian ini membuktikan bahwa kecerdasan intelektual berpengaruh negatif terhadap tingkat pemahaman akuntansi, kecerdasan emosional dan perilaku belajar berpengaruh positif terhadap tingkat pemahaman akuntansi, sedangkan kecerdasan spiritual, kompetensi dosen, dan sarana pendidikan tidak berpengaruh secara langsung terhadap tingkat pemahaman akuntansi. Penelitian ini juga menunjukkan bahwa sarana pendidikan tidak dapat memoderasi pengaruh kecerdasan intelektual, kecerdasan emosional, kecerdasan spiritual, perilaku belajar, dan kompetensi dosen terhadap tingkat pemahaman akuntansi. Jika ditinjau per indikator, maka ditemukan bahwa indikator keterampilan sosial, bersikap fleksibel, dan inteligensi praktis berpengaruh terhadap tingkat pemahaman akuntansi. Hasil ini membuktikan sebagai faktor eksternal, sarana pendidikan belum mampu memberikan kontribusi nyata dalam memengaruhi pemahaman akuntansi mahasiswa baik secara langsung maupun sebagai pendukung.

Penellitian ini memberikan kontribusi bagi pengembangan teori di bidang akuntansi pendidikan, yaitu terkait faktor yang memengaruhi tingkat pemahaman akuntansi mahasiswa agar kualitas pendidikan dapat terus diperbaiki sesuai dengan tuntutan kebutuhan dan perkembangan zaman. Bagi institusi pendidikan, penelitian ini dapat dijadikan pertimbangan dalam menetapkan kebijakan dan mengalokasikan perhatian pada faktor-faktor yang memberikan manfaat dalam peningkatan pemahaman mahasiswa terhadap suatu ilmu. Bagi penelitian selanjutnya, dapat menguji kembali variabel yang digunakan dalam penelitian ini dengan memperbanyak jumlah responden dari beberapa universitas atau dengan menyesuaikan indikator yang digunakan dalam variabel ini seperti bisa menambahkan indikator intelegensi teoritis pada variabel kecerdasan intelektual. Penelitian selanjutnya juga dapat mencari variabel lain yang berdasarkan teori memberikan pengaruh terhadap tingkat pemahaman akuntansi mahasiswa.

\section{REFERENSI}

Agustina dan Yanti, D. M. (2015). Analisis Faktor-faktor yang Mempengaruhi Tingkat Pemahaman Akuntansi Mahasiswa Jurusan Akuntansi STIE Mikroskil Medan. Jurnal Wira Ekonomi Mikrosil, 5(1), 11-20.

Daryanto, H. M. (2013). Administrasi dan Manajemen Sekolah. Jakarta: PT Rineka Cipta. 
Firdaus, A., Wispandono, RM, M., dan Buyung, H. (2019). Pengaruh Kecerdasan Intelektual, Kecerdasan Emosional, dan Kecerdasan Spiritual terhadap Kinerja Pegawai (Studi pada Kantor Kecamatan Kabupaten Bangkalan). Eco-Entrepreneurship, 5(1), 17-32.

Goleman, D. (1995). Emotional Intelligence: Why it Can Matter more than IQ. New York: Batam Books.

Laksmi, A. C., dan Febrian, R. S. (2018). Faktor-faktor Penentu Tingkat Pemahaman Mahasiswa Akuntansi. Jurnal Akuntansi dan Auditing Indonesia, 22(1), 25-35.

Laksmi, R. A., dan Sujana, I. K. (2017). Pengaruh Kecerdasan Intelektual, Kecerdasan Emosional, dan Kecerdasan Spiritual terhadap Pemahaman Akuntansi. E-Jurnal Akuntansi Universitas Udayana, 21(2), 1.373-1.399.

Listya, K., Bakar, E.A., dan Yahya, I. (2017). The Factors which Influence Accounting Student's Understanding with Spiritual Intelligence as Moderating Variable (An Empirical Study on the Student of USU, UNIMED, and UINSU). Advances in Economics, Business, and Management Research, 46, 169-175.

Maryati, S. (2017). Faktor-faktor yang Mempengaruhi Tingkat Pemahaman Akuntansi (Studi Empiris pada Mahasiswa Akuntansi IBI Darmajaya Lampung). GEMA, 9(1), 45-51.

Mulyadi, A., dan Rozak, M. A. (2019). Pengaruh Kompetensi dan Profesionalisme Dosen Akuntansi terhadap Tingkat Pemahaman Mahasiswa Akuntansi. Journal of Accounting Science, 3(1), 1-17.

Nugroho, F.B.A., Rispantyo, dan Kristianto, D. (2018). Pengaruh Kecerdasan Emosional, Kecerdasan Intelektual, Perilaku Belajar, Kompetensi Dosen, dan Fasilitas Pembelajaran terhadap Tingkat Pemahaman Akuntansi. Jurnal Akuntansi dan Sistem Teknologi Informasi, 14(2), 351-360.

Pasek, N. S. (2016). Pengaruh Kecerdasan Intelektual pada Pemahaman Akuntansi dengan Kecerdasan Emosi dan Kecerdasan Spiritual sebagai Variabel Pemoderasi. Jurnal Ilmiah Akuntansi, 1(1), 62-76.

Peraturan Pemerintah Republik Indonesia Nomor 19 Tahun 2005 tentang Standar Nasional Pendidikan.

Pitoyo, A., dan Sitawati, R. (2017). Pengaruh Sarana Prasarana Pendidikan dan Kecerdasan Emosional (EQ) terhadap Tingkat Pemahaman Akuntansi Mahasiswa dengan Minat Belajar sebagai Variabel Intervening (Studi Kasus Mahasiswa AMIK JTC Semarang Angkatan 2012-2014). INFOKAM, (1), 51-60.

Rahayu, S. I., (2019). Analisis Faktor-faktor yang Mempengaruhi Pemahaman Konsep Dasar Akuntansi. Jurnal Pajak, Akuntansi, Sistem Informasi, dan Auditing, 1(1), 40-57.

Said, A. N., dan Rahmawati, D. (2018). Pengaruh Kecerdasan Intelektual, Kecerdasan Emosional, dan Kecerdasan Spiritual terhadap Sikap Etis Mahasiswa Akuntansi (Studi Empiris pada Mahasiswa Prodi Akuntansi Universitas Negeri Yogyakarta). Jurnal Nominal, 7(1), 21-32.

Sari, I. P., dan Sartika, R. (2018). Pengaruh Perilaku Belajar, Gaya Mengajar Dosen, dan Kecerdasan Emosional terhadap Pemahaman Mahasiswa pada Mata Kuliah Pengantar Akuntansi. Menara Ekonomi, 4(2), 39-49.

Sari, L. D. N., Herawati, N.T., dan Sulindawati, N.L.G.E. (2017). Pengaruh Kecerdasan Emosional dan Perilaku Belajar terhadap Tingkat Pemahaman Akuntansi pada 
Mahasiswa Akuntansi Program S1 Universitas Pendiidikan Ganesha. E-Jurnal Universitas Pendidikan Ganesha, 8(2).

Satria, M.R., dan Fatmawati, A.P. (2017). Pengaruh Kecerdasan Emosional terhadap Tingkat Pemahaman Akuntansi pada Mahasiswa Akuntansi di Kota Bandung. Jurnal Ekonomi dan Keuangan Syariah, 1(1), 66-80.

Sternberg, R. J. (1981). A Componential Theory of Intellectual Giftedness. Gifted Child Quarterly, 25(2), 86-93.

Sudaryono, A., dan Bharata. (2004). Perilaku Belajar di Perguruan Tinggi. Jurnal Akuntansi dan Manajemen, STIE YKPN.

Suprianto, E., dan Harryoga, S. (2015). Faktor-faktor Penentu Tingkat Pemahaman Akuntansi. Jurnal Ekonomi dan Bisnis, 18(3), 75-90.

Suwardjono. (2005). Teori Akuntansi: Perekayasaan Pelaporan Keuangan. Edisi ketiga. Yogyakarta: BPFE.

Undang-undang Republik Indonesia Nomor 14 Tahun 2005 tentang Guru dan Dosen.

Zohar, D., dan Marshall, I. (2005). Memeberdayakan SC di Dunia Bisnis Terjemahan. Bandung: Mizan.

Zohar, D., dan Marshall, I. (2007). SQ: Spiritual Intelligence the Ultimate Intelligence. Bandung: Mizan Media Utama. 